\title{
HISTORICAL PARADIGM AND POLEMICS IN THE RIGHT TO FREEDOM OF SPEECH IN PUBLIC SPACE IN THE 21st CENTURY
}

\author{
Wafiyuddin Musyaffak, Moses Glorino Rumambo Pandin \\ Faculty of Humanities, Airlangga University \\ wafiyuddin.musyaffak-2020@fib.unair.ac.id; moses.glorino@fib.unair.ac.id
}

\author{
*Corresponding Author: \\ Moses Glorino Rumambo Pandin \\ Faculty of Humanities, Universitas Airlangga \\ J1. Dharmawangsa Dalam Selatan, Kampus B, Surabaya, 60286 \\ moses.glorino@fib.unair.ac.id
}

\begin{abstract}
The right to freedom of speech is a natural right owned by every human being born on earth, a gift from the Creator for his creatures, which is also included in human rights. However, with the development of the times, freedom of speech has experienced many steep paths in practice. This study aims to provide insight into how the historical and polemic paradigms are faced in freedom of speech in the 21 st-century public sphere, especially in its development and practice. The question in this research is "what is the historical paradigm in freedom of speech, and what are the phenomena and polemics in the 21 st-century public sphere?". The method used in this research is to qualitative research methods with the approaches literature review of the literature resources during the last three years, which was in 2019-2021, the 16 journals of scientific articles, one book, and four web news presented by Kompas, CNN Indonesia, and Detik.com. With the sources of the last three years being evidence of novelty, this is evidenced by the rise of hate speech on social media and there is a polemic about the Constitution of electronic information and transaction (UU ITE) which in the 21 st century is still ongoing which will be discussed in this article. The result of this study is to provide insight into the historical and polemic paradigms that occur in the right to free speech in the 21 st century by giving reliable literature with in-depth and critical evaluation. This research is expected to be recommended for the wider community, especially the academic community, so that later they can provide socialization to the public about the importance of freedom of speech following ethics. The importance of discussing this article is that the society understands the importance of the right to freedom of speech in public, especially in social media and also understands the limits of speech because there is an ITE Law that regulates this.The limitation of the research is that the sources have the same context, so that in the study, it is necessary to take a broad perspective from these sources, one of which is news sources on the internet. However, from different news stories, most of the contents are almost the same.
\end{abstract}

Keywords: democracy, freedom of speech, human rights, social media 


\section{INTRODUCTION}

Freedom of speech supports the creation of a critical society from both developed and developing countries. Because the right to freedom of speech is a human right in which the primary right is inherent in human beings, this human right has a universal and lasting nature. So it must be respected, fulfilled, and protected, which cannot be taken by anyone, ignored, or even reduced. Human life itself has experienced developments in which the product of the development of human civilization is freedom of speech. (1) The importance of freedom of speech can be felt by the wider community. Citizens can exercise their rights, in this case, to speak in public spaces effectively, either voting or participating in public policymaking. Because once again, one's freedom of speech is a fundamental human right

Through history, we can see that to achieve complete freedom of speech, great bloodshed often occurs, usually in expressing opinions or freedom of expression. If it is against a person's interests, a group or a larger group will become so quiet. In ancient history, if someone were intellectual and opposed and threatened the rules of the Church or an authoritarian government, that person would be exiled and even killed. Then, when viewed from its history, freedom of speech has long gone through a steep phase, and there are many obstacles in the interests of power.

Freedom of speech in public spaces is part of human rights $(H A M)$. The freedom of every citizen to express opinions in open public is a manifestation of democracy in the life of society, nation, and state. Human Rights are fundamental rights or basic rights brought by humans from birth given by God. (2) In essence, Human Rights include two of the most basic fundamental rights, namely the right to equality and the right to freedom. With these two foundations, other human rights can be derived. If there is no second fundamental right, then human rights will be complicated to enforce and maintain. Therefore, these basic rights must be upheld from time to time.

The right to freedom of speech which includes the right of expression and the right of opinion, is an inalienable part of human beings themselves. This right to freedom contains elements of protection, interest, and will. (3) The right to freedom is always associated with obligations and is a form of balance in social life. The balance between rights, obligations, and responsibilities is a form of balance in social life. Awareness of responsibility for every action that will impact community members must continue to be instilled. The power of responsibility affects the prudence of action.

The development of the times in freedom of speech for now is also more flexible. The existence of social media makes people more active in expressing their opinions in the general public. But in fact with this kind of freedom there are bad things such as hate speech, insults and so on, which essentially harm others. Social media has a very big impact on the development of social media and is even used by group interests in voicing something for their own interests. Therefore, social media which is used as a forum for freedom of speech must be used as it should and of course have good ethics in speaking in social media.

Freedom of speech itself has limitations in several aspects because the space of others limits our freedom, so we must be careful in speaking. Although freedom of speech is upheld and maintained, humans themselves in this freedom must have ethics in expressing speech in verbal and non-verbal forms. As long as the community defines itself by the existence 
of legal regulations, in the sense that it does not violate legal rules such as spreading hatred, slander, and so on because there is a UU ITE that regulates it, if this is not done, it will not be a problem. On the other hand, if it is not in accordance with legal regulations and violates the law, it will cause problems or conflicts and even polemics (4)

\section{METHOD}

The method used in this study is a qualitative research method, which is a descriptive method and tends to use inductive data analysis by using the protrusion of a research process and theoretical foundations so that the research focus is following the reality on the ground. In addition, it is also useful in providing an overview of the background of the research and as material in the discussion for research results(5). The approach uses a literature review which is a scientific study focusing on a particular topic. The literature review will show an overview of the development of a specific topic. The literature review will allow researchers to identify a theory or method, developed a theory, identify the gaps that occur in theory with facts on the ground or the results of the study (6)

This research focuses on freedom of speech in public spaces in the 21 st century, especially in Indonesia. In the literature itself from various sources, namely books, scientific journals that have been published and news articles Kompas, CNNIndonesia and detik. Where these sources are relevant to the topic or research problem discussed and are supportive and trustworthy. The sources used are also published in the last three years, namely 2019-2021, with novelties relevant to the 21 st century. The literature cited uses the keywords of democracy, freedom of speech, and human rights by reading and analyzing in-depth the historical paradigms and polemics regarding freedom of speech.

The technique in collecting the source literature material is done by quoting or noting things that are important to support and provide perspective on the issues regarding the views on freedom of speech discussed. It has been taken from materials such as explanations, facts, laws, literature, and others that have a relationship related to the primary research of this problem, in analyzing it using literature that is following the issues raised. Qualitative research methods can be viewed as a solution, this method through 1) observation of the literature such as books, scientific journals, and other reliable and relevant sources, 2) Interpretation and analysis of relevant documents or sources, 3) Reflection in reviewing the source of research, in this case, is freedom of speech (5).

Because this study is using qualitative research methods, it takes data from scientific journal articles and news articles supporting this research with predetermined criteria. The criteria are as follows: 1) Scientific articles using keywords that are relevant to the research conducted, namely: freedom of speech, human rights, democracy; 2) Scientific journal articles used are publications from 2019 to 2021; 3) Scientific journal articles published in trusted journals, such as Journals published by Universities, Journal of Human Rights, Journal of Legal Analogies, Journal of Law and Development, which were collected from Google Scholars and Researchgate; 4) News articles from trusted sources, namely National Kompas, Detik.com, CNNindonesia with the keywords freedom of speech, human rights and 
democracy. Literature Review does not only mean reading the literature but more towards indepth and critical evaluation and analysis of previous research on a topic.

\section{RESULT}

In the results of this study, the sources used are journal articles and news articles that contain the heads of the required survey data. For journal articles from 2019, there were five articles $(23.81 \%)$. In 2020 there were eight articles (38.10\%), while those published in 2021 were three articles (14.29\%). Then in the book published in 2019, as many as one source $(4.76 \%)$. For online news sources in 2019-2021, as many as four sources (19.05\%). With of citations of scientific journals from Google Scholar and to source news from Kompas, CNN Indonesia, and Detik.come.

Overall, the results of the analysis of the literature review in this study show that freedom of speech today is still a polemic and debate with the existence of laws and regulations in regulating freedom of speech via the internet. People also do not understand the importance of freedom of speech. Therefore, the following presents the results of data analysis in three aspects, namely:

1. The importance of freedom of speech in public spaces is seen from the historical paradigm.

Based on several sources of scientific journals and sources of news articles obtained, the view results are reviewed from the history of freedom of speech with its development. In the journal entitled Human Rights published in 2019, the history of the development of human rights, which includes freedom of speech, is as old as the history of mankind. Society has long fought for the recognition of human rights for freedom of speech. This enforcement struggle is a reaction to the authorities' arbitrary actions, which oppress the dignity of the small people. History proves it in 2000 BC; Hammurabi law in Babylon set the rules in ensuring justice for all its citizens.

The importance of seeing the history of freedom of speech for both past and present is supported by a journal article from Kristian Megahputra Warong, Caecilia JJ Waha, and Cornelius Tangkere with the research title Study of Human Rights Law Against Freedom of Opinion by Organizations, where the findings found that freedom of speech is a form of right that is inherent in all people, especially in democratic countries. Freedom of speech in human rights has an essential value that many countries respect, and efforts are made to maintain it and leave all forms of business that ignore freedom.

Furthermore, this study is also supported by a journal article from Shenty Dyan Prasasti Matias with the title Freedom of Expression According to The Theory of Freedom and the Right to Freedom of Opinion In Indonesia. It was found that freedom means that everyone has the right and can do everything according to his will, and of course, with ethics, where is space of speech wrong. Therefore, one of the fundamental rights of all individuals is the importance of freedom of speech in social life.

Data analysis from sources referred to the importance of freedom of speech in public spaces is viewed from the historical paradigm. It shows that the history of freedom of speech is very long and has gone through bloody times fighting for it, even 
today. Therefore, because of the history of its struggle, freedom of speech is essential for the life of society, nation, and state.

2. The phenomenon of freedom of speech in public spaces (Social Media)

Today's freedom of speech is very diverse in its forms, not only through direct face-to-face conversations but also using technology to use freedom of speech. According to the Scientific Article on Freedom of Opinion Against Government Through Social Media In the Perspective of the UU ITE, there are findings that the development of technology and communication is becoming increasingly rapid in its development. The presence of social media indirectly provides access to freedom of speech to the public.

The public space of social media serves as a place for exchanging ideas, ideas, and opinions. This is found in a study entitled The Meaning of Hate Speech Texts on Social Media. Social media is born, a place for someone to express their conversations and opinions in a broader public space. With this, our society has many references in knowledge outside of its positive or negative context. But there are still many obstacles with hate speech, fake news, and so on.

According to Ratih Frayunita Sari with her research entitled Questioning Too Much Opinion: Malfunctions of Social Media as a Stage for the Production of Negative Content, it was found that the presence of social media which is increasingly opening up information and causing dependence on urban people towards communication technology so that society cannot be separated from the influence of technology. This social media causes complex problems in freedom of speech in public spaces

The phenomenon that occurs with the development of social media is hate speech, which, according to Fadilatul Umroh in the title of his research Hate Speech on Social Media Networks, states that many people use it. Still, it is not by the ethics of carrying out hate speech with humiliation through writing on social media by slandering, insulting, and so on that is detrimental.

From the analysis of freedom of speech in the public sphere of the 21 st century, the development of the times with the presence of social media as a facility for increasingly widespread freedom of speech, but in fact, this phenomenon is not only for opinions and opinions. Still, it is used in bad terms such as hate speech with slander, defaming the name sound, which is detrimental.

3. Polemics on freedom of speech

The occurrence of polemics in freedom of speech can be seen with the presence of the UU ITE, which is explained in the research on the UU ITE on the Effects of Social Media on Millennial Generation, with this legislation being able to control crime on the internet, including communication through social media.

In research by Anton Hendrik Samudra with the title Defamation and Humiliation through Information and Communication Technology in Indonesia after the Amendment to the UU ITE, it is explained that the UU ITE guarantees legal certainty to the community, which in this case responds to technological developments in circulation and fulfills a sense of justice. The presence of this law has created a polemic on freedom of speech in public spaces, as in the Scientific Article of Juridical Study of the Regulation of Freedom of Expression in the UU ITE (Information and 
Electronic Transactions), explaining that rights also create obligations to respect the rights of others. However, there are no clear restrictions on this matter in the UU ITE, resulting in a polemic.

\section{DISCUSSION}

\section{The Importance of Freedom of Speech}

Freedom of speech is fundamental to be grown in society. Regardless of the quality or not, as well as pros or cons, democracy must have the same place in the eyes of government and society (7). The right to freedom of opinion and expression is the basis of democracy (8). With the freedom to speak in public and especially with technological developments, freedom of speech is facilitated more widely. It can train people's critical thinking power towards something.

Freedom of speech has been recognized internationally as one of the inherent human rights of a person. It will not interfere with the act of seeking, receiving, and transmitting information in any way. The legal system embodied in the concept of human rights is a product of a particular country and a solid foundation for all cultures and religions (9). Even historically, freedom of speech has a very high place from the perspective of human freedom itself to guarantee its development without strict rules (10). So, freedom of speech is the right of everyone without exception, not only for democratic countries but for all people. Because freedom like this is what makes a person live in the life of society.

Freedom or freedom in expressing or expressing opinions can be expressed in various forms, which can indicate that opinions or arguments can be conveyed not only orally or in writing. Statements gave certainly require space as a means of expression of the opinions to be obtained. Every living human being is entitled to the position he has as an individual with fundamental rights, such as acting, thinking, and socializing with anyone and anywhere (2), regardless of the pros and cons of that opinion. With things like this, it will train our society to think openly but critically, in the sense that our community accepts other people's views or new things but can have a filter to choose which things are following facts or just lies, thus making our society active. In looking for reliable sources, this has resulted in our community not being easy to believe in something that is not yet clear.

\section{The Historical Paradigm Freedom of Speech}

The history of the development of human rights is as old as the history of humanity. Since ancient times, every individual has fought to recognize human rights, including the right to freedom of speech (11). Recognition in freedom of speech itself has been fought for by humans in ancient times, even though freedom of speech itself is a natural right from God. But in reality, it is not like that. A person's freedom can be silenced in the past if it threatens a group, class, government, or a handful of people who have authority or power. Freedom of speech has gone through a bloody period until the freedom of speech is considered good even though there are obstacles in practice every period due to interests. 
There have been many claims for upholding human rights in its history, especially in freedom of speech, such as in $2000 \mathrm{BC}$, the Hammurabi law in Babylonia, which stipulates regulations that ensure justice for all its citizens (11). Then enters a more modern era, where this freedom occurred in the French Revolution because the king's power was so dominant and arbitrarily with his consort who spree even though the country was in a state of lethargy. This resulted in the french revolution in which the oppressed and intellectuals united in their free speech to demand human rights. There are so many historical events that have the background of freedom of speech; therefore, achieving something ideal like this requires a long process and a high price to pay.

\section{The Phenomenon of Freedom of Speech on Social Media}

The development of information and communication technology changes from day to day with messages and is increasingly modern. And it is proven to provide benefits for its users. Everyone can access information only through cell phones or other communication media, which must be connected to the internet. People of all ages and different groups can interact easily using their gadgets that are connected to the internet, which is a way of communicating and sharing information without any time limit. one of them is through social media.(12 ) Social media is an expansive public space that acts as a medium for discussion, exchanging ideas, and communicating freely and democratically. (13 )

The essential thing that society can feel today is the increasingly open and rapidly expanding information so that the space in freedom of speech is increasingly available. In comparison, now, this is an era of swift information exchange. It is where everyone has freedom of expression Through a new platform, which is now called Social media. Freedom of speech is a right that everyone is born with, and the constitution guarantees it. According to the 1945 Constitution of the Republic of Indonesia Article 28 E paragraph 3, which states that everyone has the right to freedom of association, assembly, and expression (14 )

Today, there are many social media users from various age groups, from children to the elderly, such as Facebook, Twitter, Instagram, Path, Whatsapp, Line, and so on. They were used in communication and information gathering compared to the previous era, where there was no convenience like this. Get to know the development of digital technology. In the past, when meeting new people, you would exchange business cards and residential addresses, but now with this convenience, only trading social media accounts, everything is more efficient (15). With things like this boosting from all aspects of life, even from the perspective of humans themselves, we see that the increasingly widespread internet makes it easier for someone to express their opinion. However, there are still many hate speeches on social media (16 ). In the past, when speaking in public, there must be an audience in front of directly, in contrast to now being able to express opinions through writing on social media that has an extensive reach.

\section{Polemics in Freedom of Speech}

The emergence of modern technology is beneficial for humans in exercising their freedom of speech via the internet. But human resources to respond to technology can lead to 
disorder in society. Meanwhile, nowadays, people tend to access social media, either through computers or cell phones (17). In fact, on social media, there are already many users who do not know and understand the legal basis that was set by the government, which results in users not being aware of the related consequences that can be said to be excessive in using social media. For example, posting harmful and misleading information. contains discrimination (18)

As a human right which is also included in the freedom of speech in the public sphere and one's private right, the freedom to express opinions absolutely must be protected and cannot be reduced. But remember that there are also rights that oblige one to respect others. So in practice, these rights are limited by a law currently in Indonesia, also known as the UU ITE (19). While in this law itself, there is no explicit limit on this matter.

The presence of social media itself gives people free speech and has a very high audience. With the existence of the UU ITE, the public must be careful in expressing their opinions, especially on the internet. So we should freely speak through social media. We must be cautious not to cause hoax news, hate speech that attacks someone, or information that cannot be trusted and must also prioritize the interests of others based on values and norms, and ethics. A law like this, it will control the occurrence of ethical abuse on social media.

The ITE Law does have a good purpose, but there are often polemics about this between the pros and cons. Inevitably, this has blocked the pathways that the wider community can use to correct the rules of norms that have curbed freedom of speech on the internet.(20) This law has become a stumbling block in freedom of speech or opinion, especially for Indonesian citizens in the last few years. This article becomes a ghost for the general public in expressing their views, especially on social media, where this freedom should be guaranteed in national and international law (21). The debate between the pros and cons of the polemic of free speech in the 21 st-century public sphere can be said to be complex.

\section{CONCLUSION}

In essence, freedom of speech is a perfect human right for developing a country; even to advance human reasoning, freedom of speech like this is needed. Humans are born with the right to cry and learn to speak, so this freedom is completely created by the almighty. Therefore no one can restrain it or force it in any form. If this freedom is handcuffed, there is no human side anymore because speaking, having an opinion is a gift from the Creator.

Everyone has the right to speak in public, regardless of the media. But what needs to be underlined is that the freedom of others accompanies our freedom, so we must respect others as well lest we use this freedom as a tool to bring down, destroy and deceive others. So in freedom like this, what must be remembered is ethics, morals, and of course, norms must follow each other to not cause something bad for now or in the future. Technological developments also facilitate speech, but one must be careful in using this right to freedom on social media, don't overdo it. Because if it is excessive and ends up hurting someone and is negative, there will be consequences such as social sanctions, bullying, and even punishment. So in freedom of speech, we must understand ethics and keep in mind that the freedom of others limits our freedom. 
The limitation or weakness in writing this research lies in the process. The author realizes that in research, there are many shortcomings and weaknesses. One of them is that research sources sometimes have the same context, so that in their study, it is necessary to take a broad perspective from sources that contain the same context. This takes a lot of time to understand, so it is less efficient in writing this research on the news web sources themselves on the internet using the same source results so that they must be more careful in taking scientific sources.

Recommendations from this research are conveyed in increasing public understanding and motivation in the importance of freedom of speech either through direct speech or through social media. Suggestions are addressed to the public, especially academics, to voice their opinions more about freedom of speech. So that people can learn the freedom of speech and not be afraid of threats made by individual or group interests, of course, freedom with ethics and civility.

\section{REFERENCE}

1. Marwandianto, Ardani NH. Hak Atas Kebebasan Berpendapat dan Berekspresi dalam Koridor Penerapan Pasal 310 dan 311 KUHP. J HAM. 2020;11(1):1.

2. S. Matias. Kebebasan Berpendapat Menurut Teori Kebebasan Dan Hak Kebebasan Berpendapat Di Indonesia. 2019;8(5):55.

3. Nasution L. Hak Kebebasan Berpendapat dan Berekspresi dalam Ruang Publik di Era Digital. 'Adalah. 2020;4(3):37-48.

4. Kardiyasa IM, Dewi AASL, Karma NMS. Sanksi Pidana Terhadap Ujaran Kebencian (Hate Speech). J Analog Huk [Internet]. 2020;2(1):78-82. Available from: https://doi.org/10.22225/ah.2.1.1627.78-82

5. Rukin. Metodologi Penelitian Kualitatif. Pertama. Takalar: Yayasan Ahmar Cendekia Indonesia; 2019.

6. Cahyono EA, Sutomo, Harsono A. Literatur Review: Panduan Penulisan dan Penyusunan. J Keperawatan. 2019;12.

7. Yahya AN. Survei IPI: 69,6 Persen Responden Setuju Publik Kian Takut Sampaikan Pendapat. nasional.kompas.com [Internet]. 2020; Available from: https://nasional.kompas.com/read/2020/10/25/16305891/survei-ipi-696-persenresponden-setuju-publik-kian-takut-sampaikan-pendapat

8. Irfan K. Survei: Hanya 14.6 Persen Responden Mendapat Informasi soal Hak Kebebasan Berpendapat dan Berekspresi dari Pemerintah. kompas.com [Internet]. 2020; Available from: https://nasional.kompas.com/read/2020/12/15/21241071/survei-hanya-146persen-responden-mendapat-informasi-soal-hak-kebebasan

9. Warong KM, Waha CJ, Tangkere C. Kajian Hukum Hak Asasi Manusia Terhadap Kebebasan Berpendapat Oleh Organisasi Kemasyarakatan Di Media Sosial. 2020; VIII(5):44-53. 
10. Pahad. Hate Speech (Ujaran Kebencian/Hate Speech Dan Batasan Kebebasan Berekspresi). 2020.

11. Nasution LAA, Harahap FY. Hak Asasi Manusia [Internet]. 2019. Available from: https://doi.org/10.31227/osf.io/qgkpu

12. Rahmawati N, Muslichatun, Marizal M. Kebebasan Berpendapat Terhadap Pemerintah Melalui Media Sosial Dalam Perspektif UU ITE. 2021;3(1).

13. Kusumasari D, Arifianto S. Makna Teks Ujaran Kebencian Pada Media Sosial. 2019;(9):1-15. Available from: http://dx.doi.org/10.24912/jk.v12i1.4045

14. Sari RF, Komunikasi I, Mada UG, Sosio J, No Y, Depok K, et al. Menyoal Kebebasan Berpendapat: Malfungsi Media Sosial Sebagai Panggung Produsage Konten Negatif Questioning Obsessive Argue: Social Media Mafunction as a Stage Produsage of Negative Content. 2019;

15. Umroh F. Ujaran Kebencian (Hate Speech) Pada Jejaring Media Sosial. 2020;15.

16. Antariksa K, Wp YSP, Ernawati D. Klasifikasi Ujaran Kebencian pada Cuitan dalam Bahasa Indonesia. 2019;10:164-71.

17. Samudra AH. Pencemaran Nama Baik Dan Penghinaan Melalui Teknologi Informasi Komunikasi Di Indonesia Pasca Amandemen UU ITE. 2019;50(1):91-105. Available from: http://dx.doi.org/10.21143/jhp.vol50.no1.2484

18. Perdana AP, Yusuf W. UU ITE Tentang Efek Media Sosial Terhadap Generasi Milenial. 2020;8(3):297-308. Available from: https://doi.org/10.35450/jip.v8i03.214

19. Fajariyah S. Kajian Yuridis Pengaturan Kebebasan Berpendapat Dalam UU ITE (Informasi Dan Transaksi Elektronik). 2021.

20. Rizaldi M. Kebebasan Berpendapat di Internet dan Hukum Pidana. detik.com [Internet]. 2019; Available from: https://news.detik.com/kolom/d-4647796/kebebasanberpendapat-di-internet-dan-hukum-pidana

21. Indonesia C. UU ITE Plus Buzzer, Ancaman Kebebasan Berpendapat Era Jokowi. cnnindonesia.com [Internet]. 2021; Available from: https://www.cnnindonesia.com/nasional/20210217152444-20-607439/uu-ite-plusbuzzer-ancaman-kebebasan-berpendapat-era-jokowi 


\section{ATTACHMENT}

\section{Scientific Journals And Books}

\begin{tabular}{|c|c|c|c|}
\hline No. & Researcher & Title (Year) & Result \\
\hline 1 & $\begin{array}{l}\text { Marwandianto, } \\
\text { Nasution Hilmi } \\
\text { Ardani }\end{array}$ & $\begin{array}{l}\text { Right to Freedom of Opinion } \\
\text { and Expression in the } \\
\text { Corridor of Application of } \\
\text { Articles } 310 \text { and } 311 \text { KUHP } \\
(2020)\end{array}$ & $\begin{array}{l}\text { The right formulation of } \\
\text { freedom of opinion and } \\
\text { expression in accordance } \\
\text { with Indonesian law }\end{array}$ \\
\hline 2 & $\begin{array}{l}\text { Shenty Dyan } \\
\text { Prasastu Matias }\end{array}$ & $\begin{array}{l}\text { Freedom of Expression } \\
\text { According to The Theory of } \\
\text { Freedom and the Right to } \\
\text { Freedom of Expression in } \\
\text { Indonesia (2019) }\end{array}$ & $\begin{array}{l}\text { Freedom of speech is the right } \\
\text { of everyone from birth and } \\
\text { cannot be contested and } \\
\text { cannot be regulated by others }\end{array}$ \\
\hline 3 & Latipah Nasution & $\begin{array}{l}\text { Right to Freedom of Opinion } \\
\text { and Expression in Public } \\
\text { Space in the Digital Age } \\
(2020)\end{array}$ & $\begin{array}{l}\text { Freedom of expression has } \\
\text { become wider with the } \\
\text { existence of an increasingly } \\
\text { modern digital space, so this } \\
\text { makes it easier for freedom of } \\
\text { expression }\end{array}$ \\
\hline 4 & $\begin{array}{l}\text { I Made } \\
\text { Kardiyasa, } \\
\text { Anak Agung } \\
\text { Sagung Laksmi, } \\
\text { Dewi, } \\
\text { NiMade Sukaryati } \\
\text { Karma. }\end{array}$ & $\begin{array}{l}\text { Criminal Sanctions Against } \\
\text { Hate Speech }(2020)\end{array}$ & $\begin{array}{l}\text { Hate speech that harms others } \\
\text { is an abuse of the principle of } \\
\text { freedom of speech and is } \\
\text { considered a violation of the } \\
\text { law }\end{array}$ \\
\hline 5 & Ruqin & $\begin{array}{l}\text { Qualitative Research } \\
\text { Methodology (2019) }\end{array}$ & $\begin{array}{lrr}\text { Guidelines } & \text { for } & \text { writing } \\
\text { scientific } & \text { papers } & \text { using } \\
\text { qualitative } & \text { methods } & \end{array}$ \\
\hline 6 & $\begin{array}{l}\text { Cahyono } \text { EA, } \\
\text { Sutomo, Harsono } \\
\text { A. }\end{array}$ & $\begin{array}{l}\text { Literature Review: A Guide } \\
\text { to Writing and Compiling. } \\
\text { (2019) }\end{array}$ & $\begin{array}{l}\text { Guidelines for writing and } \\
\text { compiling using literature } \\
\text { review }\end{array}$ \\
\hline 7 & $\begin{array}{l}\text { Kristina } \\
\text { Megahputra } \\
\text { Warong, } \\
\text { Caecilia JJ Waha, } \\
\text { Cornelius } \\
\text { Tangkere. }\end{array}$ & $\begin{array}{l}\text { Human Rights Law Study on } \\
\text { Freedom of Expression by } \\
\text { Social Organizations on } \\
\text { Social Media (2020) }\end{array}$ & $\begin{array}{l}\text { Regulations in human rights } \\
\text { against free speech by } \\
\text { organizations on social } \\
\text { media. }\end{array}$ \\
\hline
\end{tabular}




\begin{tabular}{|c|c|c|c|}
\hline 8 & Pahad & $\begin{array}{l}\text { Hate Speech (Hate Speech } \\
\text { and Limitations on Freedom } \\
\text { of Expression). (2020) }\end{array}$ & $\begin{array}{l}\text { Hate speech is something that } \\
\text { is not good in freedom of } \\
\text { speech and how moral ethics } \\
\text { deal with restrictions on } \\
\text { expression }\end{array}$ \\
\hline 9 & $\begin{array}{l}\text { Leoly Ahadiathul } \\
\text { Akhiriah } \\
\text { Nasution, } \\
\text { Fatrah Yunus } \\
\text { Harahap }\end{array}$ & Human Rights (2019) & $\begin{array}{l}\text { Freedom of speech is one of } \\
\text { the basic rights of human } \\
\text { rights, where this freedom is } \\
\text { present in humans from birth }\end{array}$ \\
\hline 10 & $\begin{array}{l}\text { Nur Rahmawati, } \\
\text { Muslichatun, } \\
\text { M Marizal }\end{array}$ & $\begin{array}{l}\text { Freedom of Expression } \\
\text { Against the Government } \\
\text { Through Social Media in the } \\
\text { Perspective of the ITE Law } \\
(2021)\end{array}$ & $\begin{array}{l}\text { There was agreement and } \\
\text { disagreement with the UU } \\
\text { ITE because it caused a } \\
\text { polemic over freedom of } \\
\text { speech }\end{array}$ \\
\hline 11 & $\begin{array}{l}\text { Dita Kusumasari, } \\
\text { S Arifianto }\end{array}$ & $\begin{array}{l}\text { The Meaning of Hate Speech } \\
\text { Text on Social Media (2019) }\end{array}$ & $\begin{array}{l}\text { The public space of social } \\
\text { media is no longer for } \\
\text { exchanging information, } \\
\text { thoughts, but now there is a } \\
\text { lot of hate speech for the } \\
\text { benefit of individuals or } \\
\text { groups }\end{array}$ \\
\hline 12 & $\begin{array}{ll}\text { Ratih } & \text { Frayunita } \\
\text { Sari } & \end{array}$ & $\begin{array}{l}\text { The Problem of Freedom of } \\
\text { Expression: Malfunctions of } \\
\text { Social Media as a Stage for } \\
\text { the Production of Negative } \\
\text { Content (2019) }\end{array}$ & $\begin{array}{l}\text { Freedom of speech on social } \\
\text { media is not only for } \\
\text { something positive but also } \\
\text { an arena for producing } \\
\text { negative content }\end{array}$ \\
\hline 13 & Fadilatul Umroh & $\begin{array}{l}\text { Hate Speech on Social Media } \\
\text { Networks (2020) }\end{array}$ & $\begin{array}{l}\text { Analyzing hate speech on } \\
\text { social media }\end{array}$ \\
\hline 14 & $\begin{array}{lr}\text { Kevin } & \text { Antariksa, } \\
\text { Sigit } & \text { Purnomo } \\
\text { WP, } & \text { Dra. } \\
\text { Ernawati } & \end{array}$ & $\begin{array}{l}\text { Classification of Hate Speech } \\
\text { on Tweets in Indonesian } \\
(2019)\end{array}$ & $\begin{array}{l}\text { Regarding hate speech, } \\
\text { especially in social media in } \\
\text { Indonesian }\end{array}$ \\
\hline 15 & $\begin{array}{l}\text { Anton Hendrik } \\
\text { Samudra }\end{array}$ & $\begin{array}{l}\text { Defamation and Humiliation } \\
\text { Through Information and } \\
\text { Communication Technology } \\
\text { in Indonesia Post } \\
\text { Amendment to the ITE Law } \\
\text { (2019) }\end{array}$ & $\begin{array}{l}\text { Acts of defamation with the } \\
\text { existence of communication } \\
\text { technology and excessive } \\
\text { freedom of speech through } \\
\text { gadgets }\end{array}$ \\
\hline 16 & $\begin{array}{l}\text { Andre Pebrian } \\
\text { Perdana, } \\
\text { Winardi Yusuf }\end{array}$ & $\begin{array}{l}\text { ITE Law on the Effects of } \\
\text { Social Media on Millennial } \\
\text { Generation (2020) }\end{array}$ & $\begin{array}{l}\text { The effect of social media on } \\
\text { the freedom of speech of the } \\
\text { younger generation }\end{array}$ \\
\hline
\end{tabular}




\begin{tabular}{|c|l|l|l|}
\hline 17 & Susanti Fajariyah & $\begin{array}{l}\text { Jurisdictional Review of the } \\
\text { Regulation of Freedom of } \\
\text { Opinion in the ITE Law } \\
(2021)\end{array}$ & $\begin{array}{l}\text { Regulations on freedom of } \\
\text { speech in public spaces, } \\
\text { especially on social media in } \\
\text { the UU ITE }\end{array}$ \\
\hline
\end{tabular}

\section{News Article Website}

\begin{tabular}{|c|l|l|l|}
\hline No & Author & News Source (Year) & \multicolumn{1}{|c|}{ Result } \\
\hline 1 & $\begin{array}{l}\text { Ahmad } \\
\text { Nashrudin } \\
\text { yahya }\end{array}$ & $\begin{array}{l}\text { www.nasional.kompas.com } \\
(2020)\end{array}$ & $\begin{array}{l}\text { IPI Survey: 69.6 Percent of Respondents } \\
\text { Agree The public is increasingly afraid to } \\
\text { express opinions. }\end{array}$ \\
\hline 2 & Kamil Irfan & $\begin{array}{l}\text { www.nasional.kompas.com } \\
(2020)\end{array}$ & $\begin{array}{l}\text { Only 14.6 Percent of Respondents } \\
\text { Receive Information on the Right to } \\
\text { Freedom of Opinion and Expression } \\
\text { from the Government }\end{array}$ \\
\hline 3 & $\begin{array}{l}\text { Muhammad } \\
\text { Rizaldi }\end{array}$ & $\begin{array}{l}\text { www.detik.com } \\
(2019)\end{array}$ & $\begin{array}{l}\text { Freedom of Opinion on the Internet and } \\
\text { Criminal Law }\end{array}$ \\
\hline 4 & CNN & $\begin{array}{l}\text { www.cnnindonesia.com } \\
(2021)\end{array}$ & $\begin{array}{l}\text { UU ITE Plus Buzzer, Threat to Freedom } \\
\text { of Expression in Jokowi's Era }\end{array}$ \\
\hline
\end{tabular}

